\title{
Key factors for the design of integrated library systems in universities
}

\section{Fatores-chave para o projeto de sistemas integrados de gestão de bibliotecas nas universidades}

\author{
Edison Patricio Cisneros-Corrales ${ }^{1}$, Yadira Lizbeth Acosta-Lozano ${ }^{2}$ \\ ${ }^{1}$ Pontifícia Universidade Católica do Equador, Quito, Equador. ORCID: https://orcid.org/0000-0002-2590-8512 \\ 2 Universidade Internacional SEK, Quito, Equador. ORCID: https://orcid.org/0000-0003-3685-6882
}

Mail to/Autor para correspondência/Correo a: Edison Patricio Cisneros-Corrales, epcisneros@hotmail.com

Submitted/Recibido: 21 de outubro de 2020; Approved/Aceptado: 2 de março de 2021

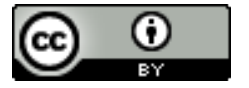

Copyright (C) 2021 Cisneros-Corrales \& Acosta-Lozano. All journal content (including directions, editorial policy and templates) is under a Creative Commons license Attribution 4.0 International. By being published by this journal, articles are free to use in educational, research and non commercial environments, with mandatory attribution of authorship. To further information check http://revistas.ufpr.br/atoz/about/submissions\#copyrightNotice.

\begin{abstract}
Introduction: the university libraries are constituted as a key space to fulfill the educational, investigative and linking objectives of universities and higher education centers. The irruption and extensive use of technology has impacted the daily life of libraries, forcing them to implement new processes of automation and innovation. The Integrated Library Systems are presented as cutting-edge solutions to improve obsolete library services. However, when designing one of these systems, flaws are evident regarding the factors on which greater efforts must be focused for its successful production. Based on this problem, the study tries to identify the key factors for the design of Integrated Library Systems Method: the study uses the Matrix of Cross Impact Multiplications Applied to Classification or MICMAC method to generate a Structural Analysis. Results: the result established that the factors: intuitive design, flexibility, interconnection, and portability are the key factors for the design of integrated library systems in universities. Conclusion: the key factors identified can guarantee educational centers success, with efficiency and money savings, in their path to the design of integrated library management systems.
\end{abstract}

Keywords: Integrated Library System (ILS); Automation; University libraries; Structural analysis; Educational technology; MICMAC.

\begin{abstract}
Resumo
Introdução: as bibliotecas universitárias constituem-se como um espaço fundamental para cumprir os objetivos educativos, investigativos e articuladores das universidades e dos centros de ensino superior. A irrupção e o uso extensivo da tecnologia tem impactado o dia a dia das bibliotecas, obrigando-as a implantar novos processos de automação e inovação. Os Sistemas Integrados de Bibliotecas são apresentados como soluções de ponta para melhorar os serviços de bibliotecas obsoletas. No entanto, ao projetar um desses sistemas, ficam evidentes as falhas quanto aos fatores nos quais maiores esforços devem ser direcionados para sua produção bem-sucedida. Com base neste problema, o estudo tenta identificar os fatores-chave para o projeto de Sistemas Integrados de Bibliotecas? Método: o estudo usa a Matriz de Multiplicações de Impacto Cruzado Aplicada à Classificação ou o método MICMAC para gerar uma Análise Estrutural. Resultados: O resultado estabeleceu que os fatores: design intuitivo, flexibilidade, interconexão e portabilidade são os fatores chave para o design de sistemas integrados de bibliotecas nas universidades. Conclusão: os fatores-chave identificados podem garantir o sucesso dos centros educacionais, com eficiência e economia, no caminho para o desenho de Sistemas Integrados de Gestão de Bibliotecas.
\end{abstract}

Palavras-chave: Sistemas Integrados de Gestão de Bibliotecas (SIGB); Automação; Bibliotecas universitárias; Análise estrutural; Tecnologia educacional; MICMAC.

\section{INTRODUCTION}

University libraries are a key part of the objectives of higher education institutions. Their contribution is invaluable to the processes of education, research, and community outreach, playing a central role as a resource for literacy, education, information provision, and learning.

The emergence of technology as a factor that shapes social dynamics has impacted the functioning of university libraries, forcing them to adopt new processes that allow them to maintain their leading role. Because of this, the libraries aim to implement computer systems that allow the automation of processes, being the Integrated Library System (ILS) the appropriate tool.

The objective of this research article is to identify the key factors involved in an ILS, in order to highlight them as the central point in the design and subsequent implementation processes. Doing this allows educational centers to establish a series of relevant criteria that allow an efficient approach towards a successful design.

The document maintains four sections. The first section consists of a literature review where the academic literature on libraries, universities, integrated library management systems, and structural analysis are addressed. The second one deals with the methodology where the different phases for the implementation of the method are described. The third section presents the results achieved after the application of the method. Finally, the article addresses several final reflections concerning the research. 


\section{LITERATURE REVIEW}

\section{Libraries, universities, and integrated library management}

The names given to libraries have been diverse according to the peculiarities of situations and contexts. These include public, university, specialized, national, and international libraries, among others. Likewise, libraries are as diverse in their types as they are concerning their contents/lines of knowledge (art, philosophy, science, history) and materials (books, magazines, documents, etc.) (Salas, 2019).

González (2014) states that libraries have maintained a priority position in society. Its origin is prior to the universities; however, its affiliation to educational institutions allowed a deep development in terms of scientific and informative activities. González-Solar (2016) states that the university maintains education, research, and links with society as its main objectives. Libraries are one of the central pillars for the fulfillment of these three objectives. In education, as an asset for learning; in research, as a center that hosts and allows for the collection of information that aims to generate new knowledge; and in the linkage with society, as a space for the development of research that contributes to the social fabric and society's productivity.

On the other hand, Esponda and Matar (2018) state that in universities, libraries also play an important role in the quality of education. The relationship is established on the basis that a greater number of scientific research projects reflects university excellence and to achieve this a study space such as libraries is ideal for the fulfillment of these purposes.

By maintaining a constant need for information, society tries to satisfy this desire by resorting to public and private centers where knowledge is kept. Under this context, libraries are corroborated as the social space that openly guarantees information. Its importance is transcendental to the point that international organizations, such as the United Nations Educational, Scientific and Cultural Organization (UNESCO), have established that libraries represent an asset of great importance for literacy, education, information provision and consequent economic, social and cultural development of societies (Segoviano Hernández \& Palomo González, 2010).

Historically, library services have been improved through internal operations, which are not very noticeable and often invisible to the users. However, nowadays it is the user who plays a leading role because his or her needs and expectations feed the action of improving these spaces. The automation processes are necessary for a good performance that seeks the satisfaction of the user and the development to the maximum of its potential (Ortega, Ureta, Felipe, \& Moreira, 2018).

Contemporaneity has motivated great changes in social dynamics. Here technology has intervened, presenting itself as synonymous with improvement and transition. Universities, not being the exception to this reality, recurrently implement new and avant-garde technologies that allow them to improve learning and teaching. For Quintero, Arias, Giraldo, and Bermúdez-Hernández (2019), libraries, as a service attached to higher education, present the need to innovate with these technologies.

Authors such as Montero (2020), Alonso-Arévalo and Vázquez-Vázquez (2018) and García, Facciano, and Cortés (2016) state that the new era forces libraries to move out of their comfort zone, constantly promoting transformations to enable the management of large flows of information and safeguarding efficiency in order to maintain their relevant role in the shaping of new knowledge.

Considerations like this lead Sánchez and Sánchez (2018) to affirm that the use of Information and Communication Technologies (ICT), together with the implementation of computer systems in the library context, have unleashed a digital revolution that points towards the automation of its services. Likewise, Pisté and Marzal (2018) state that the role of new libraries is to improve their services in terms of quality, efficiency, innovation, and technology.

Under this situation that the concept of Integrated Library Systems (ILSs) emerges. For León-Moreno and Zapico-Alonso (2014), ILSs are defined as a set of different software, used for the integrated management of the various administrative and documentary processes in libraries. According to Sánchez and Sánchez (2018), these systems maintain the purpose of synthesizing in a single application what is involved in the management of libraries, including a centralized management of databases that avoids the duplication of information and speeding up the efficiency of processes in libraries by providing users with digital documents, reliable and copyrighted.

Regarding the characteristics of ILSs, many authors argue about the main characteristics they should have. Marcel and Faustin (2020) establish that important factors to be considered in ILSs are permanent availability of data in the library, capacity for users to do complex searches, an inbox for suggestions from users, recurrent reports and tracking of lost books. Hardyanto, Purwinarko, and Adhi (2018) mention that some outstanding factors to be considered are the capacity to carry out various tasks and processes, library retrieval, web-based data access, easiness to be used, and perception of usefulness as the main predictor for using the system. Ponelis and Adoma (2018) consider the following factors: flexibility (understood as the ability to add additional functionality if the institution needs changes), price to acquire, affordable maintenance, and easiness of use. 
Olatunji, Farouq, and Idris (2018) consider important factors some such as architecture and design, no restrictions in the use with different electronic types of equipment, capacity for user to set their own priorities, permanent access to the full catalog, compatibility, and capacity to run on local area networks without access to the Internet. Moruf, Sani, and Abu (2020) mention factors such as compatibility with other systems/platforms, low or no licensing cost, capacity to configure according to the needs of the library, proficiency in safeguarding the security of all data. Finally, Mammadova (2017) considers the permanent access to the online catalog, local host of the data, ability to modify the program's source code, and friendliness with the user as important factors in ILSs.

To conclude this section, it is mandatory to mention that the implementation of ILSs is presented as a successful process; in fact, its use allows libraries to contribute greatly to learning management, research management, and knowledge management (Esponda \& Matar, 2018). However, in certain contexts ILSs domination is coming to an end, new technologies with a wider range of resources and useful for the management of libraries have been developed in recent years.

Kouis and Agiorgitis (2020) state that libraries' information systems have gone through a process of redesigning and reconstruction; this process started with the introduction of ILSs, then moving on into Library Management Systems (LMSs) and arriving to Library Service Platforms (LSPs). The latter one is currently considered as the third generation of library management systems and outstands since it is capable of using cloud computing and web technologies that enable an efficient management of physical, digital and electronic materials in a single unified system (Pradhan, 2019).

Without a doubt technologies as LMSs and LSPs are more efficient and complete if compared with ILSs, nevertheless, as mentioned by Breeding (2015), the use of ILS is still and will continue as a viable option for the foreseeable future, indeed he predicts that ILSs will coexist among with LMSs since ILSs continue evolving and adopting new characteristics, that are until some point considered similar to those offered by LSPs. This last statement allows us to infer that ILSs maintain their usefulness in the management of libraries, especially for the context of this research, where library management systems are not widely used.

\section{Structural Analysis}

Once we have analyzed the relevance of libraries, their close relationship with universities, and their potential evolution with the implementation of an Integrated Library Systems, it is necessary to introduce the issue of structural analysis.

According to Godet (2007), structural analysis is a tool for collective reflection that structures a reality. Employing a matrix of relations between factors, it provides the description of a system, allowing the establishment of key factors according to the context of the system analyzed (Benjumea-Arias, Castañeda, \& Valencia-Arias, 2016; Pedro, Leitão, \& Alves, 2019; Pérez Uribe \& Vargas, 2016).

Through a graph of influence and dependence, the factors to be analyzed are established, which will be located in four different zones. The zones are classified as follows:

- Power Zone, which is located in the upper left of the plane. This zone houses the determining and environmental factors.

- Conflict Zone located in the upper right part of the plane. This zone shows those primordial factors, thus housing the key factors and the objective factors.

- Independent Zone, which occupies a place in the lower left part of the plane. Here we present those factors that are not of great importance to the system; this space houses both the autonomous and secondary factors.

- Exit zone, located in the lower right part of the map, where the result factors are located (Martelo, Jiménez-Pitre, \& Villabona-Gomez, 2017).

Likewise, there are several types of factors that are located according to a graph of influences and dependencies (Figure 2). 


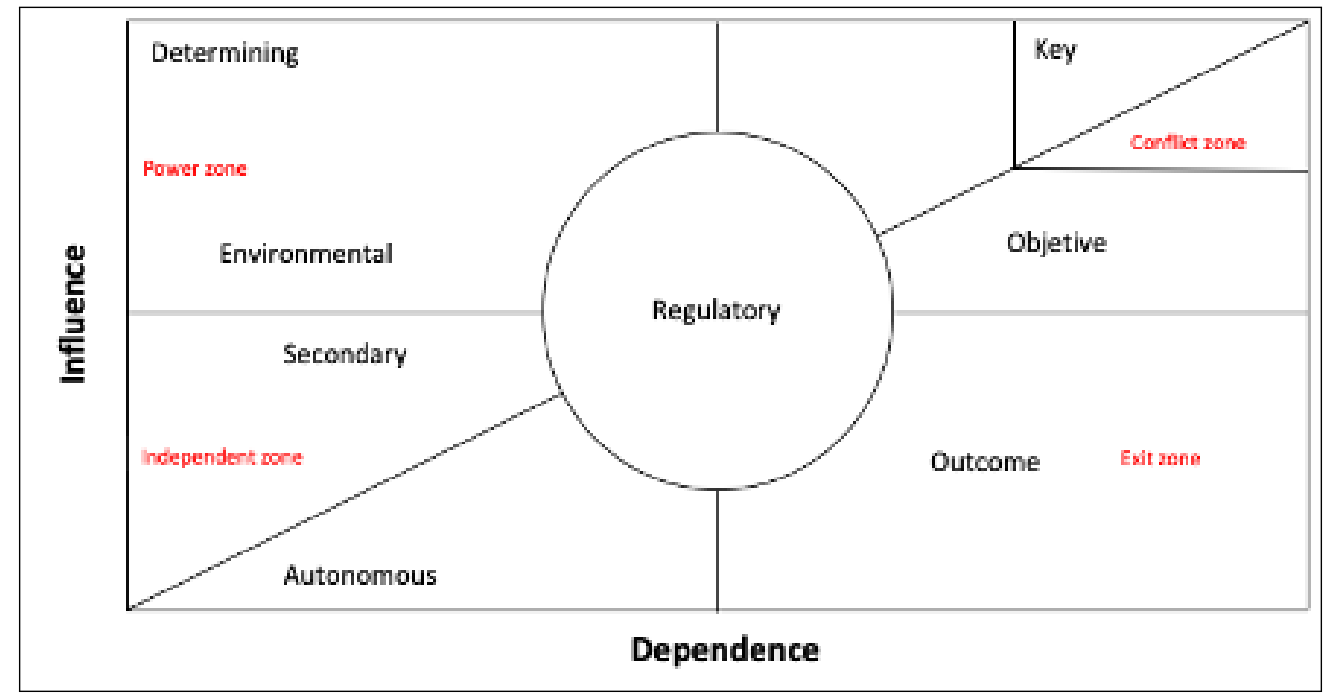

Figure 1. Factors located in indirect influences/dependencies map. Source: own elaboration, 2021.

Arango Morales and Cuevas Pérez (2012) describe the different types of factors as follows:

- - Autonomous factors are those considered as of little influence and little dependence, their nature relegates them to not be a determining part of the future of the system.

- Key factors, also called challenge factors, are of great influence and dependence in the system. Their behavior establishes the normal functioning of the system; therefore, it defines the dynamics of the system itself. Their importance is high in the study because from these the challenges of the system are determined.

- Determining factors are those characterized as having little dependence and great influence. They are considered to be of high importance since their behavior determines the continuity or existence in the future of the system.

- Environmental factors are of little dependence and medium influence; their importance in the system is relatively low.

- Regulatory factors take their place in the central area of the plane. In normal situations, these are the factors that allow the operation of the system. They are important factors because they maintain a relationship with the whole spectrum and therefore are a source for achieving the objectives to be set.

- Secondary factors are those distinguished for being of little influence and little dependence; therefore, they are considered of low importance for the evolution and functioning of the system.

- Objective factors are located in the central part of the matrix, they are very dependent and moderately influential. These factors can be influenced to achieve the desired goal.

- Outcome factors are characterized by their low influence and high dependence. Their behavior is based on the interaction with other factors.

The presented categorization establishes eight well-defined groups. These factors will occupy a specific space in the indirect influences/dependencies map. Identifying the key factors will be the main objective in a structural analysis study.

\section{METHODOLOGY}

This document focuses on describing and highlighting the key factors related to the design of Integrated Library Systems, through a prospective structural analysis. To carry out the structural analysis, the tool Matrix of Cross Impact Multiplications Applied to Classification; better known as MICMAC, will be used (Godet, 2007).

Martelo, Jiménez-Pitre, and Villabona-Gomez (2020) establishes that the structural analysis is executed in three phases. The first phase consists of generating an inventory of system factors. This is done through a participatory reflection of professionals or experts who are part of the system. Depending on the knowledge and experience of these experts, a list of factors is generated. With the list of factors, a homogenization is carried out where those factors that are repeated and/or similar are debugged, generating a final list (Martelo et al., 2017). In this final listing, a keyword and an explanation of the factor is established (Pinto, 2008).

The second phase consists of the description of the relationships between the factors. For this purpose, the factors of the final list are coupled in a structural matrix, which are distributed in rows and columns. The 
purpose of this stage is to evaluate, in a systematized way, the influence that each of the factors has on each other (Zambrano, Morales, Cordero, \& Pérez, 2013). For this purpose, a numerical estimate was made by the experts, expressed as follows: strong influence (3), moderate influence (2), weak influence (1), no influence (0), and potential influence $(\mathrm{P})$. The process is carried out with the assistance of the software MICMAC version $5.3 .0^{1}$.

The third and final stage is to identify the key factors of the system. In this last one, the results obtained are presented using two graphs that allow an easy appreciation of the results. The first one is a map of indirect influences/dependencies where the factors are classified according to their position in the plane, allowing the clear identification of those factors considered the key ones. Likewise, the plane of direct influences is presented, which allows us to determine those factors that exert a high influence concerning other or others (Arango Morales, Garza Villegas, Cuevas Pérez, Leyva Cordero, \& Estrada Camargo, 2012).

\section{RESULTS AND DISCUSSION}

In the first stage, corresponding to the generation of a factor inventory, eight (8) professionals from four (4) higher education institutions from Ecuador were selected. These professionals had to meet the following selection criteria:

- Person in charge of the library, head of library or any other similar denomination.

- Minimum experience of 5 years (including proven experience in the development and/or implementation of Integrated Library Systems).

- Full-time employee (at least 40 working hours per week).

- Fourth level academic title.

Once the experts were selected they were all assembled in a participatory workshop. There, the main ideas of the academic literature regarding ILSs were presented and analyzed. Afterward, in combination with the experience and knowledge of the experts about the system studied, 18 factors related to Integrated Library Management Systems were identified. Subsequently, as mentioned by Martelo et al. (2017) a debugging process was carried out in which a final list of 14 factors were agreed upon arguments presented by the experts, which allowed to exclude the repeated and/or similar factors (Table 1).

\begin{tabular}{|l|l|l|l|}
\hline N. & Factor & Code & Explanation (description) \\
\hline 1 & Remote Access & AR & $\begin{array}{l}\text { Easy access for developers from a different location } \\
\text { to the headquarters. }\end{array}$ \\
\hline 2 & Automation & AUTO & $\begin{array}{l}\text { Arrangement of processes, activities, and services in } \\
\text { digital format. }\end{array}$ \\
\hline 3 & Correction & CORR & $\begin{array}{l}\text { Ability to modify according to the objectives of the } \\
\text { institution. }\end{array}$ \\
\hline 4 & Intuitive design & DI & Ease of understanding for use/handling \\
\hline 5 & Interface Aesthetics & Edl & Degree of visual attraction. \\
\hline 6 & Flexibility & FLEX & Easy for developers to modify/edit. \\
\hline 7 & Search Functionality & FdB & Suitability for quick access to information. \\
\hline 8 & Interconnection & INT & $\begin{array}{l}\text { Correct hyperlinks depending on the desired destina- } \\
\text { tion/link. }\end{array}$ \\
\hline 9 & Control mechanism & MdC & Availability of indicators to measure performance. \\
\hline 10 & Offline operation & OffL & Availability to work without an Internet connection. \\
\hline 11 & Customization & PER & Ability to modify the interface according to the user. \\
\hline 12 & Portability & PORT & Faculty to be used in different types of equipment. \\
\hline 13 & Security & SEG & Perception of risks and external threats. \\
\hline 14 & Usability & US & Level of usefulness for learning. \\
\hline
\end{tabular}

Table 1. Factors identified.

Source: Own elaboration (2021).

In the second stage, corresponding to the description of the relationships between the factors, using a Direct Influences Matrix (Table 2), an evaluation of influences between the factors identified was developed. By consensus among the experts, a total of 182 responses were collated according to the 14 factors identified [(14 $\mathrm{x} 14)$ - 14]. The numerical value was assigned under the following criteria: 3 for a strong influence, 2 for a

\footnotetext{
${ }^{1}$ The software can be downloaded from the web page http://en.laprospective.fr/ in the section "Methods of Prospective".
} 
moderate influence, 1 for a weak influence, 0 for no influence, and $\mathrm{P}$ for a potential influence. The process was carried out with the assistance of the MICMAC software version 5.3.0.

\begin{tabular}{|l|l|l|l|l|l|l|l|l|l|l|l|l|l|l|}
\hline & $(1)$ & $(2)$ & $(3)$ & $(4)$ & $(5)$ & $(6)$ & $(7)$ & $(8)$ & $(9)$ & $(10)$ & $(11)$ & $(12)$ & $(13)$ & $(14)$ \\
\hline 1:AR & & 3 & 1 & 1 & 1 & 3 & 0 & 1 & 1 & 0 & 1 & 1 & 1 & 3 \\
\hline 2:AUTO & 3 & & 2 & 3 & 3 & 3 & 3 & 3 & 2 & 3 & 3 & 3 & 3 & 3 \\
\hline 3:CORR & 1 & 2 & & 2 & 1 & 2 & 1 & 2 & 1 & 2 & 2 & 2 & 2 & 2 \\
\hline 4:DI & 1 & 3 & 2 & & 2 & 3 & 3 & 3 & 1 & 3 & 3 & 3 & 3 & 3 \\
\hline 5:EdI & 1 & 2 & 2 & 2 & & 2 & 2 & 3 & 2 & 2 & 1 & 2 & 2 & 2 \\
\hline 6:FLEX & 3 & 3 & 2 & 3 & 3 & & 2 & 3 & 2 & 3 & 3 & 3 & 3 & 3 \\
\hline 7:FdB & 3 & 3 & 2 & 2 & 2 & 2 & & 3 & 3 & 3 & 1 & 3 & 1 & 2 \\
\hline 8:INT & 3 & 3 & 3 & 3 & 3 & 3 & 3 & & 3 & 3 & 2 & 3 & 3 & 3 \\
\hline 9:MdC & 1 & 3 & 2 & 3 & 3 & 3 & 3 & 3 & & 3 & 3 & 3 & 3 & 3 \\
\hline 10:OffL & 1 & 2 & 2 & 3 & 3 & 3 & 3 & 3 & 3 & & 3 & 3 & 3 & 3 \\
\hline 11:PER & 1 & 2 & 1 & 2 & 1 & 1 & 2 & 2 & 2 & 1 & & 3 & 2 & 1 \\
\hline 12:PORT & 3 & 3 & 2 & 3 & 2 & 3 & 3 & 3 & 3 & 3 & 3 & & 3 & 3 \\
\hline 13:SEG & 3 & 2 & 2 & 2 & 2 & 3 & 2 & 2 & 2 & 3 & 2 & 3 & & 2 \\
\hline 14:US & 1 & 1 & 2 & 3 & 2 & 1 & 1 & 3 & 2 & 2 & 1 & 2 & 2 & \\
\hline
\end{tabular}

Table 2. Direct Influence Matrix. Source: Own elaboration (2021).

The result of the matrix developed led to the third stage, where the type of factors in Integrated Library Systems were identified through a Map of Indirect Influences/Dependencies (Figure 2). The resulting categorization grouped the factors in the following zones: power zone [(MdC and FdB)], conflict zone [(AUTO, OffL, SEG, DI, FLEX, PORT and INT)], independent zone [(CORR, EdI, PER and AR)] and exit zone [(US)].

Likewise, the factors were named according to their location as follows: determining factors $[(\mathrm{MdC})]$, secondary factors $[(\mathrm{CORR})]$, autonomous factors [(AR and PER $)]$, regulatory factors [(EdI and FdB $)]$, outcome factors [(US)], objective factors [(SEG, OffL and AUTO)] and key factors [(INT, PORT, FLEX and DI)].

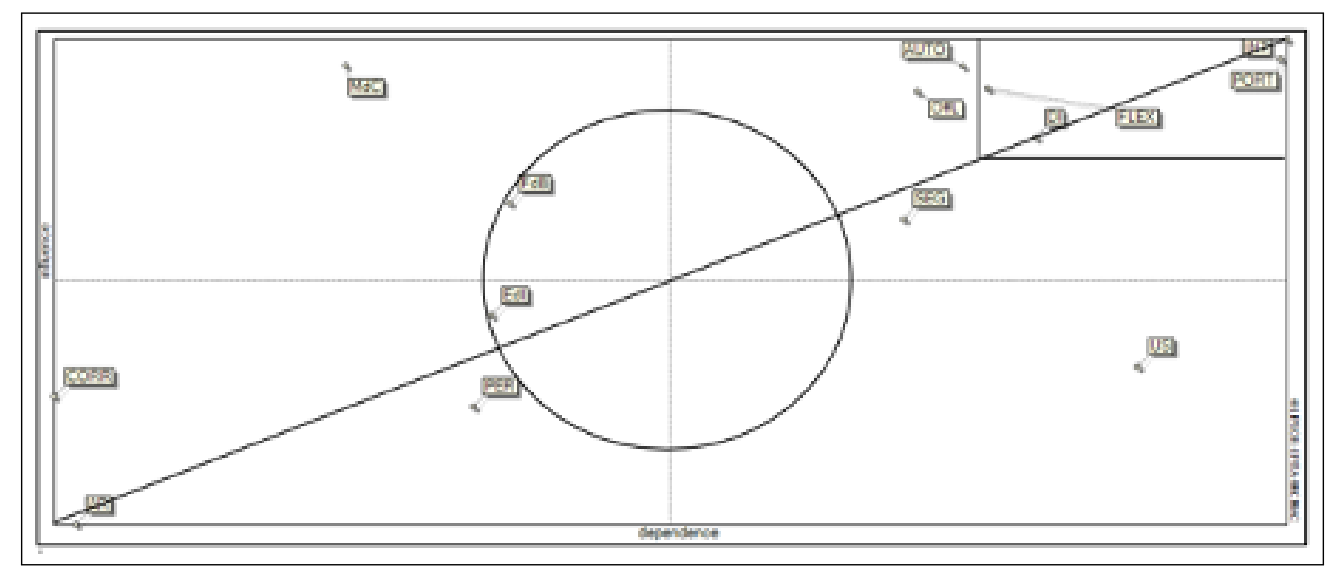

Figure 2. Factors located in indirect influences/dependencies map.

Source: own elaboration, 2021.

In studies of this kind, the key factors are those of primary importance since by prioritizing actions related to these, it is possible to achieve the desired changes. Consequently, intuitive design, flexibility, interconnection, and portability are the factors that should be given priority for the design of integrated library systems in higher education institutions.

To conclude, it was considered as significant to determine those factors that have a high influence concerning to their peers. For this purpose, the indirect influence plane is presented (Figure 3). This plane exhibits the influence between factors at a representation level of $5 \%$ which is equivalent to the simplest possible, in other words, it shows the influence of the main factors analyzed. The level of influence is divided into five categories: weakest influences, weak influences, moderate influences, relatively strong influences, and strongest influences. 


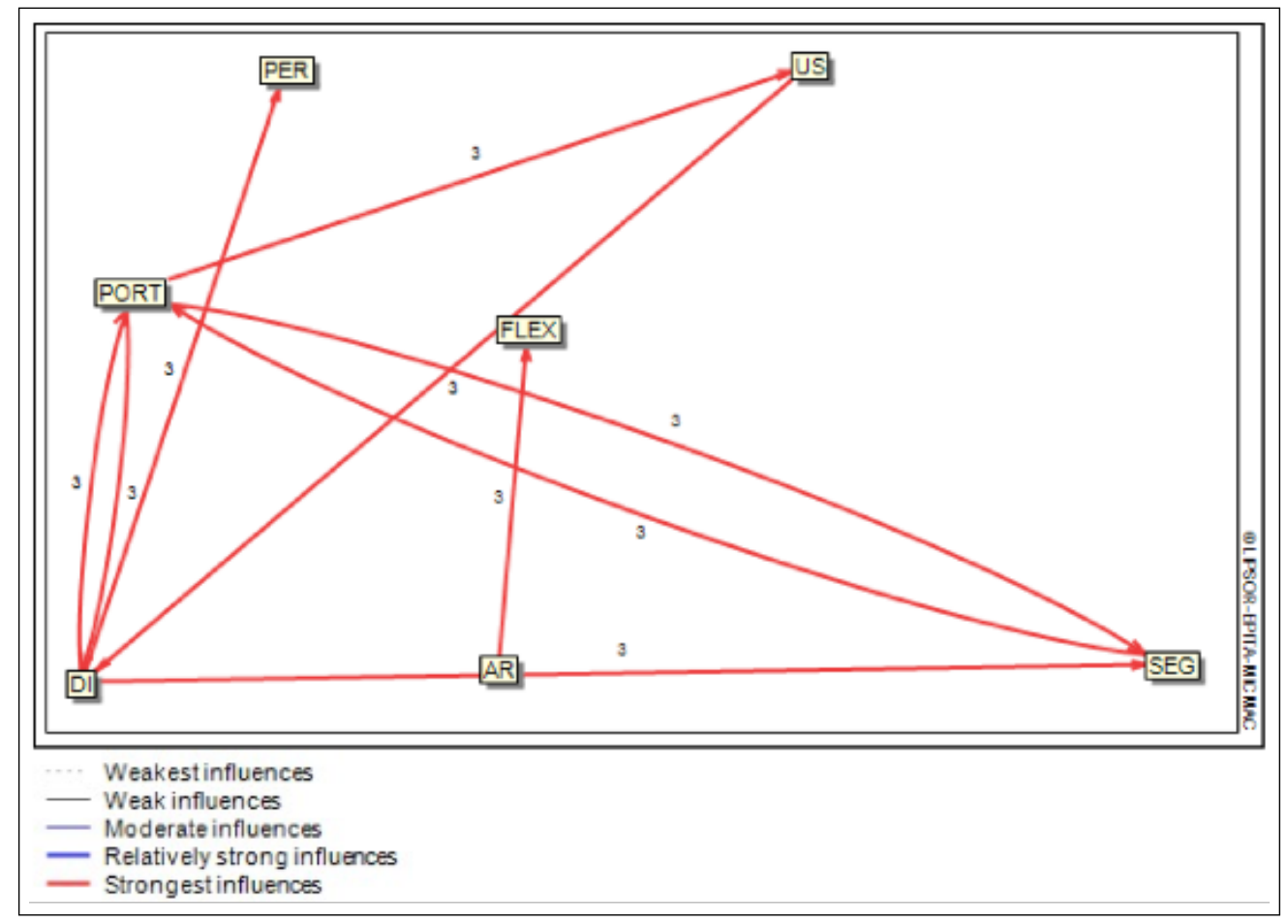

Figure 3. Factors located in indirect influences/dependencies map. Source: own elaboration, 2021.

The plane shows that all the factors, at this level of representation, have a strong level of influence among them. The plane also establishes that the factor portability (PORT), influences in a reciprocal way both, the security factor (SEG) and the intuitive design factor (DI). Its high degree of mutual influence allows us to conclude that to achieve the optimal design of an ILS it is necessary to establish and to control, in an integrated manner, the actions that affect these three factors.

\section{FINAL REFLECTIONS}

The study pointed the key factors in the design of Integrated Library Systems (ILSs). This study is useful since it allows decision-makers to prioritize actions that focus on the key factors identified; actions taken with this approach increase the likelihood of achieving an efficient ILS. The study identified four (4) key factors: intuitive design, flexibility, interconnection, and portability. Prioritizing these factors and working deeply with them will subsequently have an impact on other factors such as automation, offline operation, security and usability.

Besides this central result, a series of additional conclusions were obtained based on the research and the sections covered:

The introduction of the new technological era brought with it a series of transformations in society. Libraries have had to adapt to new technologies in order to meet the demands of users in constant need of knowledge and information. In this context, Integrated Library Systems are presented as a potential tool for the development of management systems to reach the forefront of teaching, learning, and community outreach.

The structural analysis method allows classifying the various factors of a system based on the experts' appreciation. In this process, the MICMAC tool plays a leading role because it allows the identification of the key factors of a system.

Additionally, the study used a selection of experts based on certain pre-established qualifications. It became clear that when selecting experts, it is essential that they have the necessary experience, expertise, and credentials to qualify as connoisseurs of the system.

Finally, the evaluation of influence/dependence factors generates a logical result (key variables) that serves as a starting point for making appropriate decisions that will assist in the creation of a competent, practical and useful library management system.

\section{ACKNOWLEDGEMENTS}

The authors would like to thank the group of experts for their generosity of time with the study; without their knowledge this research would not have been possible. 


\section{REFERENCES}

Alonso-Arévalo, J., \& Vázquez-Vázquez, M. (2018). La contribución de la biblioteca universitaria al logro de los planes y proyectos de la institución. Cuadernos de Documentación Multimedia, 29(1), 42-53. doi: 10.5209/CDMU.60033.

Arango Morales, X. A., \& Cuevas Pérez, V. A. (2012). Método de análisis estructural: matriz de impactos cruzados multiplicación aplicada a una clasificación (micmac) (Tese de Doutorado). Universidad Autónoma de Nuevo León, Nuevo León, Ménxico.

Arango Morales, X. A., Garza Villegas, J. B., Cuevas Pérez, V. A., Leyva Cordero, O., \& Estrada Camargo, M. (2012). Estudio exploratorio de variables a través de análisis estructural micmac en la prestación del servicio en la administración pública municipal de monterrey méxico. Revista Internacional Administración \& Finanzas, 6(2), 73-88.

Benjumea-Arias, M., Castañeda, L., \& Valencia-Arias, A. (2016). Structural analysis of strategic variables through micmac use: Case study. Mediterranean Journal of Social Sciences, 7(4), 11-19. doi: 10.5901/mjss.2016.v7n4p11

Breeding, M. (2015). Library services platforms: A maturing genre of products. Chicago: American Library Association.

Esponda, E. P., \& Matar, R. P. (2018). La calidad de la biblioteca universitaria y sus ventajas para la formación en educación superior. Revista Cubana de Educación Médica Superior, 32(1), 219-228.

García, L., Facciano, C., \& Cortés, T. (2016). Bookcrossing: experiencia en una biblioteca universitaria. In 10 encuentro de bibliotecarios de la provincia de córdoba. Córboda, Argentina.

Godet, M. (2007). La caja de herramientas de la prospectiva estratégica. Paris: Laboratoire d'Investigation Prospective et Stratégique.

González, O. (2014). Escenarios 2020 para la biblioteca universitaria cubana: Red de bibliotecas de la universidad de la habana (Tese de Doutorado). Universidad de Granada, Granada, Espanha.

González-Solar, L. (2016). La biblioteca universitaria orientada a la investigación: propuesta de un modelo de servicio centrado en el usuario desde la perspectiva del marketing (Tese de Doutorado). Universidade da Coruña, La Coruña, Espanha.

Hardyanto, W., Purwinarko, A., \& Adhi, M. A. (2018). Enduser satisfaction analysis on library management system unnes using technology acceptance model towards national standard of integrated library. Journal of Physics: Conference Series (983). doi: 10.1088/1742-6596/983/1/012006

Kouis, D., \& Agiorgitis, G. (2020). Library service platforms (lsps) characteristics classification and importance ranking through delphi method application. International Information \& Library Review, 52(1), 1-15. doi: 10.1080/10572317.2020.1840001

León-Moreno, J. A., \& Zapico-Alonso, F. (2014). Sistema integrado de gestión bibliotecaria para extremadura en software libre. Cuadernos de Documentación Multimedia, 25, 18-24. doi: 10.5209/rev_CDMU.2014.v25.47473.

Mammadova, V. (2017). Integrated library systems: selection and implementation issues. Library Science and Bibliography, 2(41), 80-92.

Marcel, G., \& Faustin, U. (2020). Development of an online integrated library management information system:
Case study "university of gitwe". International Journal of Scientific Research in Computer Science an Engineering, $8(2), 65-76$.

Martelo, R., Jiménez-Pitre, I., \& Villabona-Gomez, N. (2017). Determinación de factores para deserción de estudiantes en pregrado a través de las técnicas lluvia de ideas y micmac. Revista Espacios, 38(20), 1-9.

Martelo, R., Jiménez-Pitre, I., \& Villabona-Gomez, N. (2020). Uso del análisis estructural para caracterizar variables de calidad educativa en institución de primaria y secundaria venezolana. Educación, 29(56), 170-190. doi: 10.18800/educacion.202001.008

Montero, J. U. (2020). Propuesta de un sistema integrado de gestión bibliotecaria para el sistema de bibliotecas municipales de la municipalidad de san josé. Bibliotecas, 38(1), 1-27. doi: 10.15359/rb.38.1.1.

Moruf, H. A., Sani, S., \& Abu, Z. I. (2020). Open source automation software: Stirring automated to integrated library system. Journal of Applied Sciences and Environmental Management, 24(7), 1273-1278. doi: 10.4314/jasem.v24i7.21

Olatunji, S. O., Farouq, B. L., \& Idris, M. (2018). Adoption of integrated library management software (newgenlib): The experience of kano university of science and technology library, wudil, kano state. Library Philosophy and Practice(2140). Retrieved from https://digitalcommons.unl.edu/ libphilprac/2140/

Ortega, J. M. P., Ureta, G. D., Felipe, M. D. R. C., \& Moreira, M. M. M. (2018). Sistema de control de préstamos de activos electrónicos para la biblioteca central de la universidad técnica de manabí. Polo del Conocimiento: Revista Científico-profesional, 3(12), 298315. doi: $10.23857 /$ pc.v3i12.837.

Pedro, E., Leitão, J., \& Alves, H. (2019). The intellectual capital of higher education institutions. Journal of Intellectual Capital, 20(3), 355-381. doi: 10.1108/JIC-072018-0117

Pérez Uribe, R. I., \& Vargas, H. A. (2016). El uso del método micmac, para la definición de procesos de intervencién en las organizaciones. Mediterranean Journal of Social Sciences, 11(1), 92-105. doi: 10.18667/cienciaypoderaereo.156

Pinto, J. P. (2008). Las herramientas de la prospectiva estratégica: usos, abusos y limitaciones. Cuadernos de Administración(40), 47-56. doi: 10.25100/cdea.v24i40.403

Pisté, S., \& Marzal, M. A. (2018). Bibliotecas universitarias y educación digital abierta: un espacio para el desarrollo de instrumentos de implementación en web y de competencias en información e indicadores para su evaluación. Revista Interamericana de Bibliotecología , 41 (3), 277-288. doi: 10.17533/udea.rib.v41n3a06.

Ponelis, S. R., \& Adoma, P. (2018). Diffusion of open source integrated library systems in academic libraries in africa. Journal of Physics: Conference Series, 39(6/7), 430-448. doi: 10.1108/lm-05-2017-0052

Pradhan, P. (2019). Library services platform (lsp): An overview. Inflibnet, 26(1), 12-22.

Quintero, E., Arias, N. A., Giraldo, J. P. P., \& BermúdezHernández, J. (2019). Estrategias para la implementación de los códigos bidimensionales quick response (qr) en las bibliotecas universitarias. Revista CIES Escolme, 10(2), 92-109.

Salas, J. M. (2019). Biblioteca digital. Vida Cientifica 
Boletín Científico de la Escuela Preparatoria N. 4, 7(14), $1-5$.

Sánchez, L. S., \& Sánchez, R. C. (2018). Sistema de gestión bibliotecaria abcd 3.0. Revista Publicando, 5(14, 3), 423433. Retrieved from https://revistapublicando.org/revista/ index.php/crv/article/view/1278.

Segoviano Hernández, J., \& Palomo González, M. Á. (2010). Factores que motivan el uso de la biblioteca universitaria. Innovaciones de negocio, 7(14), 373-390.

Zambrano, V. R., Morales, X. A., Cordero, O. L., \& Pérez, V. C. (2013). Identificación de variables clave del perfil docente en ciencias políticas/identification of key variables of the teaching profile in political science. Cuadernos de Administración, 3(6).

How to cite this article (APA):

Cisneros-Corrales, E. P. \& Acosta-Lozano, Y. L. (2021).

Key factors for the design of integrated library systems in universities. AtoZ: novas práticas em informação e conhecimento, 10(2), 49 - 57.

Retrieved from: http://dx.doi.org/10.5380/ atoz.v10i2.76846 